\title{
VDAC3 wt Allele
}

National Cancer Institute

\section{Source}

National Cancer Institute. VDAC3 wt Allele. NCI Thesaurus. Code C51095.

Human VDAC3 wild-type allele is located in the vicinity of 8p11.2 and is approximately 14 $\mathrm{kb}$ in length. This allele, which encodes voltage-dependent anion-selective channel protein 3 , plays a role in adenine nucleotide translocation. 